\author{
Angela Kuznyetsova, \\ Dr.Sc., Professor, Banking University, Ukraine \\ D ORCID ID,0000-0003-3590-7625 \\ email: angel@ubs.edu.ua \\ Olha Klishchuk, \\ Banking University, Ukraine \\ iD ORCID ID,0000-0001-5376-1450 \\ email: oklischyk@gmail.com \\ Andrew Lisnyak, \\ Banking University, Ukraine \\ ORCID ID, 0000-0003-4493-676X \\ email: lisnyakAYe@gmail.com \\ Atik Kerimov, \\ Dr.Sc. Professor, Azerbaijan State University of Economics, Azerbaijan \\ email: atik_karimov@unec.edu.az \\ ORCID ID, 0000-0003-2493-6180 \\ Azer Babayev, \\ Ph.D., Azerbaijan State University of Economics, Azerbaijan \\ ORCID ID, 0000-0002-9067-7562 \\ email: azer_babayev@unec.edu.az \\ Correspondence author: oklischyk@gmail.com
}

\title{
INNOVATION MECHANISM IN MONETARY POLICY FORECASTING: UNIFICATION OF ALL MACROECONOMIC PUZZLES IN SVAR MODEL
}

Abstract. The article is devoted to developing a forecasting mechanism unifying all macroeconomic puzzles, which violate fundamental macroeconomic relationships among variables of the monetary transmission mechanism in Ukraine. The violations mentioned above caused by breaking one-law price (PPP puzzle), uncovered interest rates rule (UIP puzzle), plausible emergence of new sophisticated financial instruments and causality of international risk-sharing conditions under the financial capital spillover. The authors calculated the residuals in the VAR model of monetary transmission mechanism (MTM) to analyze the correlations between shocks and disturbances in these variables. Furtherly these correlations were put in constructing the restriction matrix for building structural vector autoregressive model. The correlations between shocks and disturbances were employed for estimating the impulse response functions used for determining the duration of half-life shocks for the real exchange rate. The obtained results allowed noticing that relationships between macroeconomic variables in the monetary transmission mechanism were not similar if considering the established foreign exchange arrangement. In particular, during 2007-2020, relationships among MTM variables were violated. Besides, a half-life duration of the real exchange rate was far longer. While in cases for Ukraine before switching to floating exchange rate regime and after it became less explicit and half-lives were shorter. The findings allowed confirming the impact of the currency arrangement switching on violation of traditional linkages between the variables of foreign exchange rate channel of MTM. Thus, it showed that during the fixed arrangement, absolutely all reactions were violated. Although after the introduction of a flexible exchange rate, the sign of REER correlation with foreign trade terms has changed to positive and more strengthened. Therefore, it has demonstrated a positive impact on the dynamics of real GDP and lower inflation. The findings of the current study could be used to improve existed methodical approaches for establishing structural constraints on variables responses to the shock of the exchange rate. The algorithm for designing optimal monetary policy strategies could take place in empirical data and forecasting exchange rate volatility.

Keywords: PPP puzzle, UIP puzzle, MTM, financial innovations, REER, SVAR.

Cite as: Kuznyetsova, A., Klishchuk, O., Lisnyak, A., Kerimov, A., \& Babayev, A. (2020). Innovation Mechanism in Monetary Policy Forecasting: Unification of all Macroeconomic Puzzles in SVAR Model. Marketing and Management of Innovations, 4, 219-230. http://doi.org/10.21272/mmi.2020.4-17 
Introduction. During the last decade, the scientific researches focused on investigating the violations of fundamental macroeconomic relationships among variables of the monetary transmission mechanism of the central banks. The problem of non-parity pricing of local currencies is known as purchasing power parity pricing puzzle. In turn, this problem increased exposure to shocks of financial capital flows and the emergence of new innovative financial instruments, which increased the impact of shocks of financial spillovers. At the same time, based on the classical monetary concept or Keynesian theory, monetary variables should have a close relationship with each other. However, empirically they do not have it or have but with the opposite sign of correlation. That forces scientists to review traditional hypotheses in existing dynamic stochastic models or autoregressions to improve the reliability of their forecast results calculated to evaluate the relevant monetary policy measures of the regulator.

Literature review. Monetary transmission is partially subject to deformation under the influence of violation of the law of single price between different trading partners. Purchasing Power Parity Law (PPP or single price rule) is the most famous model of foreign exchange rate balance. Based on the PPP, the dynamics of the exchange rate should reflect the long-term equilibrium price of one country's currency concerning the currency of another country. Following the essence of the concept of PPP (Rogoff, 1996), the price of the same product must be the same anywhere in a world in which all trade restrictions are lifted. However, Rogoff K. noticed that the nominal effective exchange rate in historical retrospective is characterized by persistent volatility. It is associated with the presence of an autoregressive process in its trend. In this regard, the return to the equilibrium value of the exchange rate requires much more time than half-life duration for «sticky» prices (i.e., nominal wages, administratively regulated prices, indirect taxes etc.) that can be 3-5 years (Chari et al.,2002).

Meese and Rogoff (1983) indicated that the nominal exchange rate follows the random walk process $(\mathrm{RW})$, which is not always sustainably correlated with fundamental macroeconomic variables. In turn, it is a significant problem for economists engaged in macroeconomic modelling.

For the reasons of violation of conventional macroeconomic dependencies in the monetary transmission mechanism (MTM), there is a low correlation of trade terms with a real exchange rate which possesses a sufficiently high level of volatility. However, the equilibrium of the trading account should contribute to low fluctuations in the foreign exchange market. The reason lies in the different price-setting for homogeneous export commodities (Atkenson and Burstein, 2008). That is, the decorrelation between the REER and commodities prices (mostly non-value-added goods), is an obstacle to the central bank's monetary policy impulse spreading towards its ultimate goal through MTM. For export commodities, the fact of moderate volatility is confirmed compared to the observed volatility of the foreign exchange rate (Engel, 2016). In the paper (Backus and Smith,1993) Breaking the fundamental relationships showed that the level of consumption in the economy did not decrease with the high level of volatility of the REER. This study demonstrated lower volatility compared to the foreign exchange rate. Herewith, in the work of Kollmann (1995) and Benigno and Thoenissen (2008), the authors denied the hypothesis that under high devaluation economic agents reduce consumption and begin saving more and invest their temporarily free funds in contingent financial assets. In turn, Valchev (2020) observed that violation of the rules of uncovered interest rate parity led to a violation of the conventional relationship between the interest differential and logarithm of the forward and spot exchange rate ratio. Besides, it could lead to a decrease in the transmission dependency between the interest rate channel and the foreign exchange rate. Several scientists focused on the highlighting of other factors and prerequisites for violation of one price rule and uncovered interest rate parity. In particular, Itskhoki and Mukhin (2017) found that:

- the law of one price is violated due to the presence of strategic complementarities in pricing reducing the sensitivity of consumer prices to the movement of foreign exchange rates; 
A., Kuznyetsova, O., Klishchuk, A., Lisnyak, A., Kerimov, A., Babayev. Innovation Mechanism in Monetary Policy Forecasting: Unification of All Macroeconomic Puzzles in SVAR Model

- the real economy is not an economy with perfect free trade, because in factual circumstances it is necessary to consider the presence of protectionist measures of influence such as import tariffs and export subsidies;

- weak interchangeability between domestic and imported goods reducing the correlation between the consumption of the households and the foreign exchange rate;

- low elasticity between goods-subsidies of domestic and imported origin;

- the reason for the change in consumer preferences in the home economy (host economy in the two-country model) is due to the level of openness of the economy: the more open economy is, the less elasticity in consumption and greater volatility in the financial market;

- the emergence of asymmetry in the rule of uncovered interest parity (UIP - Uncovered Interest Purities) is because the shock of monetary policy on the volume of consumption is inconsistent with the volatility of the real exchange rate due to the presence of nominal inertia (rigidities).

Ukrainian scientist Petryk (2008) applied these assumptions in the calibration of the QMF model (Quarterly Macroeconomic Forecasting Model) used by the NBU in macroeconomic forecasting. The author engaged in the application of the hypothesis about violations of traditional ties between interest rates and foreign exchange rates. There are four types of fundamental relationships violations have been formed in economic literature:

- violation of the law of single pricing for all goods;

- persistent and higher foreign exchange rate volatility compared to nominal rigidities;

- violation of the correlation between the level of consumption and volatility of the exchange rate;

- violation of the law of uncovered interest parity.

Therefore, the task of this article is to investigate all these violations in the domestic realities and to offer a single methodology for considering these violations simultaneously in the structural model of a vector autoregression. In turn, it would improve the algorithm of forecasting the exchange rate path for modelling optimal strategies for conducting monetary policy.

Mussa (1986) noted that these violations become more explicit and obvious if, in a country, the currency arrangement changed from fixed to flexible. Therefore, there is an evident need to identify the change in the relationship between macroeconomic variables in Ukraine before and after switching from the fixed arrangement to the free-floating of the foreign exchange rate. Besides, it is essential to implement these patterns into the macroeconomic structural model of a vector autoregression.

Methodology and research methods. The focal point of this paper is a forecasting mechanism of monetary transmission impulses delivered by macroeconomic variables which could be hurt by the range of causes. These causes include price setting among different countries, violation of uncovered interest rate parity setting among developed and developing economies, low export and import substitution level, autocorrelation in macroeconomic time series etc. Thus, the offered mechanism should unify all existing macroeconomic puzzles and violations and simultaneously account for the identification requirement of the SVAR instrument. The study approach includes next steps:

- to conduct the correlation and regression analysis aimed to assess the strength and direction of relationships between macroeconomic variables in MTM;

- to build the restriction matrix, based on investigated violations and obstacles on spreading impulse from one variable to another;

- to estimate the maximum number of restrictions (equation 7) which satisfies the feasible condition;

- to reduce the number of restrictions to the maximum number of feasible restrictions by choosing the most significant ones; 
- to develop the SVAR model using the maximum log-likelihood estimation method, which allows identifying the coefficients for unrestricted parameters of the AR process and innovations, i. d. parameters of shocks that took place in the model.

Results. For the study of the main violations in the relationships between REER and macro-financial indicators, the curves of dependencies are constructed, and $\mathrm{R}^{2}$ and correlation coefficients are calculated. At first glance, there is no violation between the nominal market exchange rates and the real effective exchange rate. Appreciation of REER by $53.5 \%$ and $55 \%$ contributes to the strengthening of cash rates of purchase and selling respectively and by $51 \%$ of the official NBU rate. Therefore, the coefficient of determination in the regression model of the REER and the cash selling exchange rate is the highest $(95 \%)$ among them.

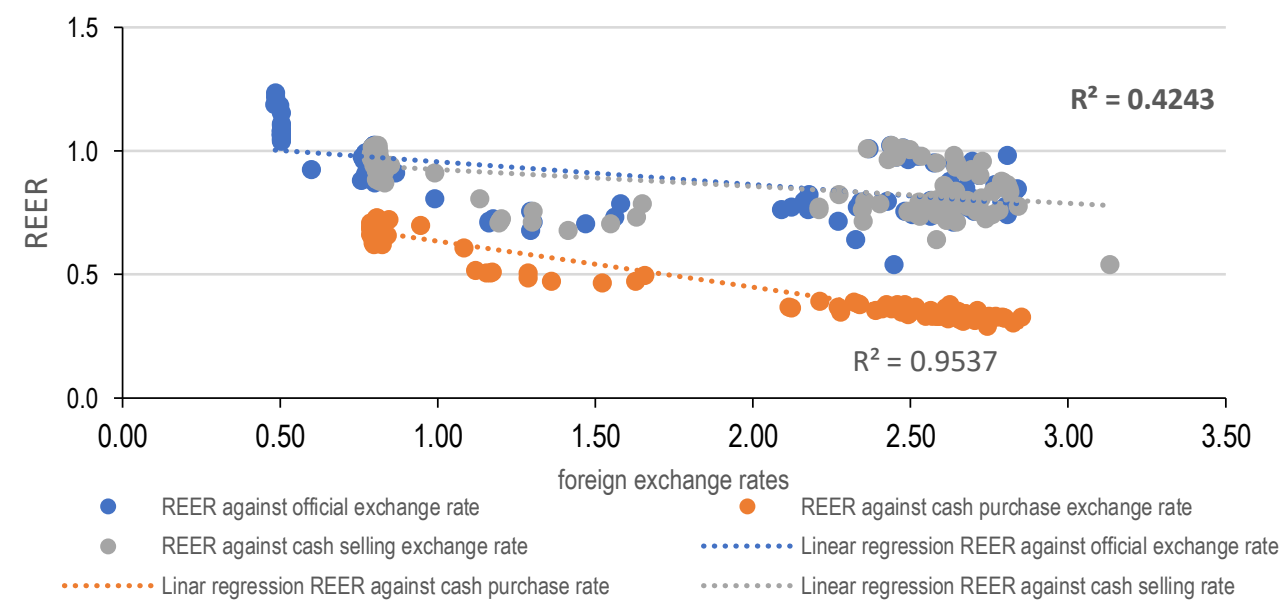

Figure 1 Empirical relationship between REER and the value of different foreign exchange rates Sources: developed by the authors on the basis of (NBU, 2020a).

A positive correlation is observed between REER and NEER. However, the strength of the relationship is lower by $15 \%$ (Itskhoki and Mukhin, 2017) and coincided with domestic conditions observed in Ukraine.

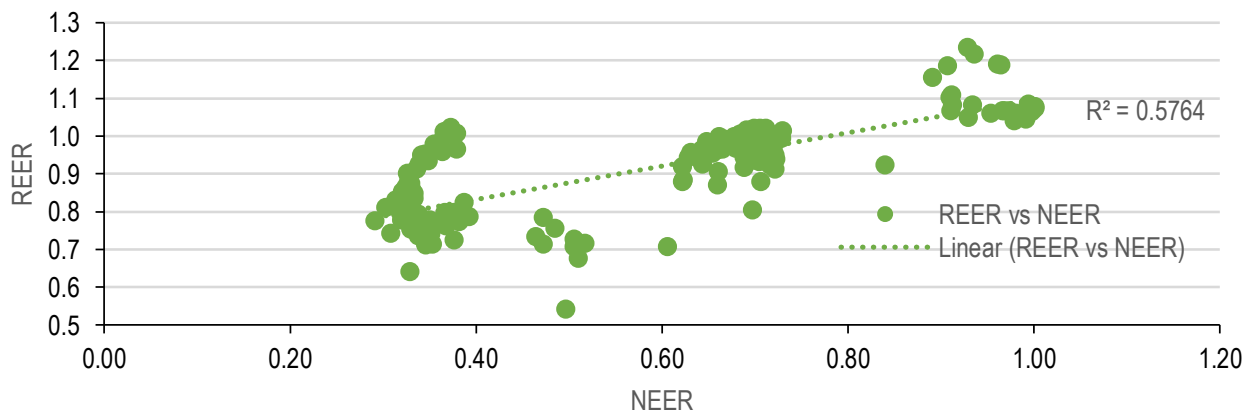

Figure 2. Empirical relationship of REER and NEER

Source: developed by the authors on the basis of (NBU, 2020a). 
A., Kuznyetsova, O., Klishchuk, A., Lisnyak, A., Kerimov, A., Babayev. Innovation Mechanism in Monetary Policy Forecasting: Unification of All Macroeconomic Puzzles in SVAR Model

Figure 3 demonstrates that the correlation coefficient between the strengthening of the real exchange rate and the level of total consumption was controversial (79\%). Therefore, it means that the higher purchasing power of exchange rate adjusted on prices, the lower the level of consumption would be. Besides, this supports the low level of determination coefficient, as shown in figure 3.

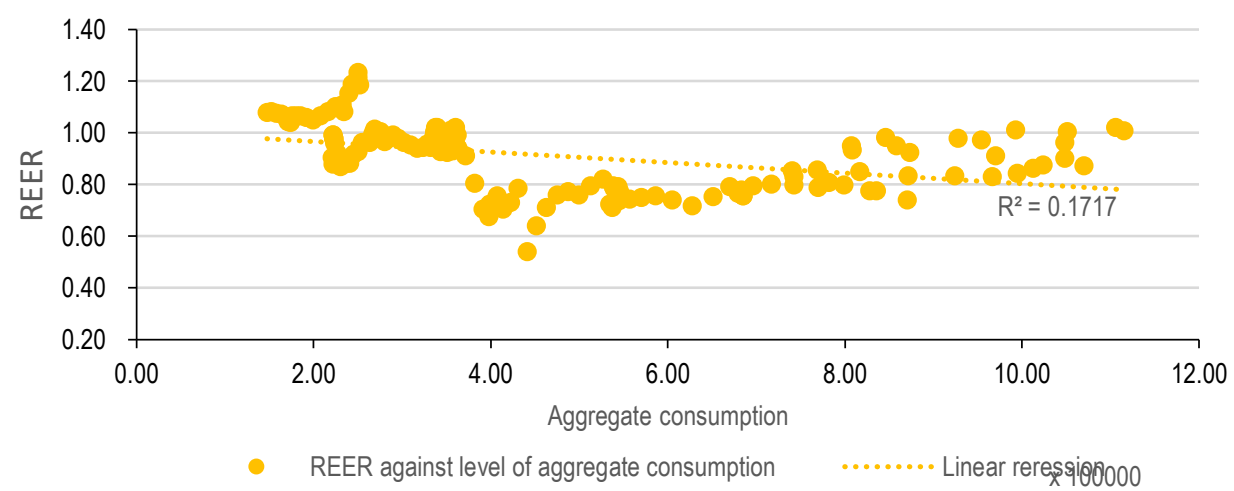

Figure 3. Empirical linkages between REER and aggregate consumption in the economy

Sources: developed by the authors on the basis of (NBU, 2020a; State statistics service of Ukraine, 2020).

The results of the empirical analysis indicated that the devaluation of the exchange rate does not force a decrease in the level of consumption in Ukraine, but provokes its growth. In turn, it contradicts the classical Keynesian concept. This discrepancy Itskhoki and Mukhin (2017) explained that the financial shock did not affect the change in consumer behaviour of households due to the reluctance or distrust to the making investments in existing financial assets. In case of violations of uncovered interest parity rules, it has been approved for Ukraine's conditions, because the coefficient of determination $\left(R^{2}\right)$ in the regression of the exchange rate from the interest differential was equal to $50 \%$. Thus, it indicates a low level of a dependency. The dependence between the REER and the terms of trade (the ratio of exports to imports) evidenced the negative correlation. It demonstrated a slight level of dependency, while the NEER showed a higher level of correlation, indicating different levels of volatility of the REER and NEER (Figure 4).

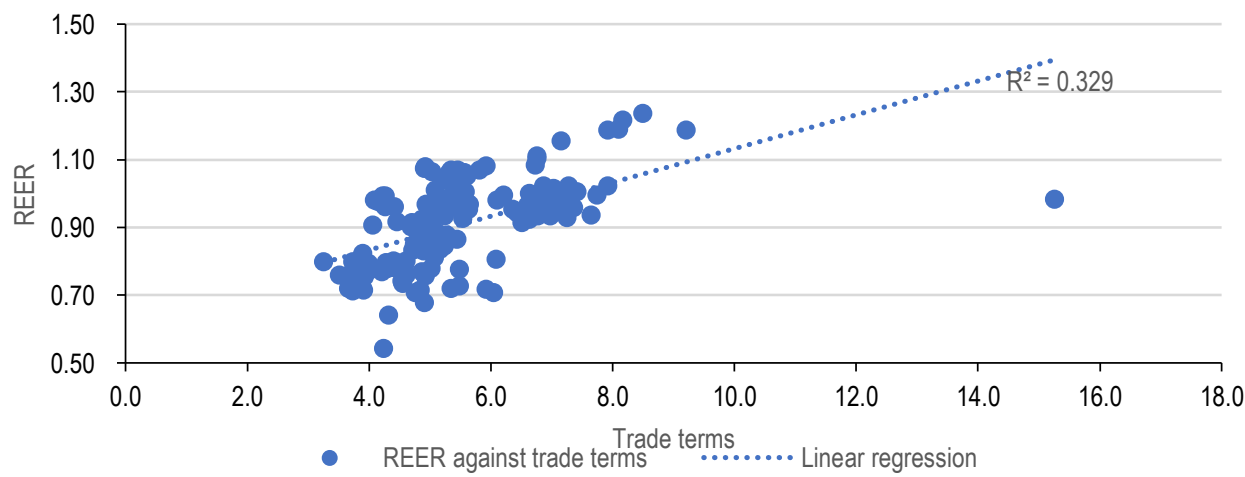

Figure 4. Empirical link between REER and trading conditions in the economy

Sources: developed by the authors on the basis of (NBU, 2020a). 
Furthermore, the volatility of the real effective exchange rate outweighed the nominal almost threefold. It means that the exchange rate adjusted on consumer prices volatility loses dependency from the trade balance of the balance of payments. Based on such conclusions, it is possible to forme the hypotheses about the establishment of restrictions on the structural model of spreading the impulse of the REER by using the monetary transmission mechanism scheme.

In this case, the SVAR identification tool of the model was used. In turn, the method of maximum loglikelihood estimation allowed calculating as follows: the coefficients were set to unrestricted parameters of the AR process $\left(y_{t-p}\right)$ and the moving average $\left(\varepsilon_{t-q}\right)$. The following formulas (1-3) depict the equations for determining the matrix of coefficients in parameters for SVAR models:

$$
\begin{aligned}
& A y_{t}=A_{1}^{*} y_{t-1}+\cdots+A_{p}^{*} y_{t-p}+B \varepsilon_{t}, \\
& y_{t}=A^{-1} A_{1}^{*} y_{t-1}+\cdots+A^{-1} A_{p}^{*} y_{t-p}+A^{-1} B \varepsilon_{t}, \\
& y_{t}=A_{1} y_{t-1}+\cdots+A_{p} y_{t-p}+B u_{t},
\end{aligned}
$$

where $A_{t-p}^{*}$ - coefficient at variable imposed by restrictions; $B^{*}$ - the coefficient for shocks caused by each variable.

Minimizing the function of maximum log-likelihood allowed evaluating the parameters:

$$
\operatorname{Ln}\left[L_{c}(A, B)\right]=-\frac{K T}{2} \operatorname{Ln}(2 \pi)+\frac{T}{2} \operatorname{Ln}|A|^{2}+\frac{T}{2} \operatorname{Ln}|B|^{2}-\frac{T}{2} \operatorname{tr}\left(A^{T} B^{-1^{T}} B^{-1} A \overline{\Sigma_{\mathrm{u}}}\right),
$$

where $K$ - number of variables; $T$-sample volume reduced on one lag; $t r$ - upper triangular matrix under $L U L^{-1}$ factorization; $\overline{\Sigma_{u}}-$ covariation shock matrix, divided by $A$ matrix.

The setting of equations of the model was calculated like a conventional vector autoregression with a single lag. This lag was equal to 161 levels of freedom depending on the specification with the inclusion of the time trend. The data sample includes the period from 2007 to 2020 (until July) with a monthly frequency. Restrictions on the transmission of impulses by variables foreign exchange rate channel are reflected in the matrices $A^{*}$ and $B^{*}$. Matrix $A^{*}$ sets limits on the identification of parameters at $y_{t-p}$, while the matrix $B^{*}$ - on moving average parameters. The matrix of endogenous variables included inflation expectations, trading conditions, real GDP, consumer prices, administratively regulated prices, producer prices, core inflation and Ukraine's interest rate differential with the European Union rates. This differential is calculated based on statistical data of the European Central Bank and the NBU. For meeting condition of the matrix reversibility and non-exceedance of the maximum possible number of restrictions, it is necessary to manage the equality:

Number of restrictions $=2 K^{2}-\left(\mathrm{K}^{2}+K(K-1) \cdot 0,5\right)$

The formula mentioned above allowed concluding that the maximum number of restrictions should not exceed 45. Thus, based on established empirical dependencies and existing hypothesis of macroeconomic violations, in the proposed model, the number of imposed restrictions was 39 out of 45. The sample consisted of 163 number of observations. The observations were divided into two samples, covered the period before the switching to the flexible exchange rate arrangement and after. 
A., Kuznyetsova, O., Klishchuk, A., Lisnyak, A., Kerimov, A., Babayev. Innovation Mechanism in Monetary Policy Forecasting: Unification of All Macroeconomic Puzzles in SVAR Model
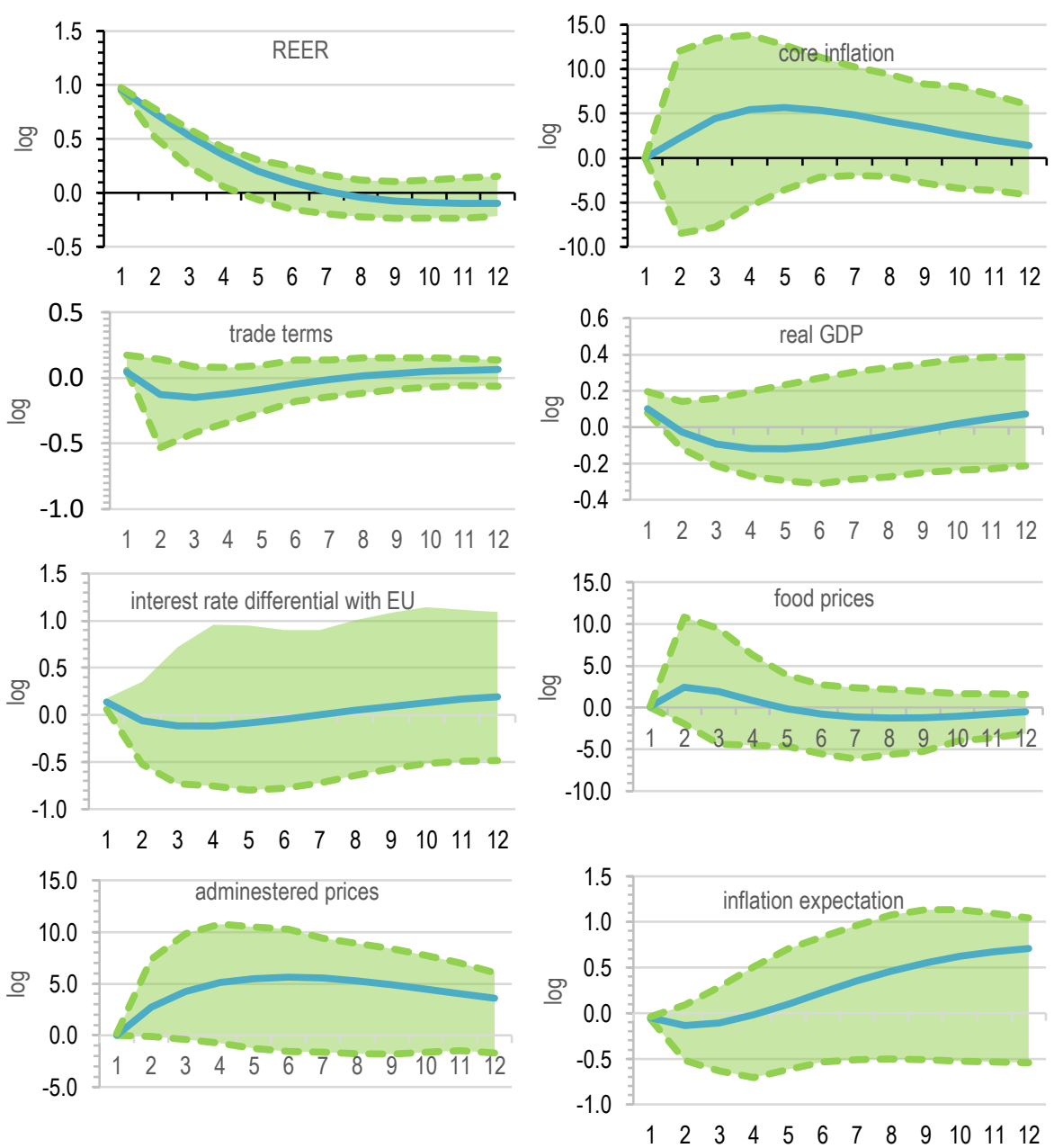

Figure 5. Impulse response functions to REER shock for the first sample (forecasts are presented in the differentiated and logged form and at the $95 \%$ of confidence level)

Sources: developed by the authors.

Based on correlational dependencies established by empirical estimations, the following matrix $A^{*}$ defined the restrictions on regression parameters at $y_{t-p} \operatorname{AR}(1)$.

$$
A^{*}=\left(\begin{array}{ccccccccc}
N A & 0 & N A & N A & 0 & 0 & 0 & 0 & 0 \\
& N A & 0 & N A & N A & N A & N A & N A & 0 \\
& & N A & N A & 0 & 0 & 0 & 0 & 0 \\
& & & N A & 0 & 0 & 0 & 0 & 0 \\
& & & & N A & N A & N A & 0 & 0 \\
& & & & & N A & N A & 0 & 0 \\
& & & & & & N A & N A & N A \\
& & & & & & & & \\
& & & & & & & & \\
& & & & & & & &
\end{array}\right.
$$


In turn, matrix $B^{*}$ demonstrates the restrictions for model disturbances.

$$
B^{*}=\left(\begin{array}{cccccccccc}
1 & & & & & & & & \\
0 & 1 & & & & & & & \\
N A & 0 & 1 & & & & & & \\
N A & 0 & N A & 1 & & & & & \\
N A & 0 & N A & 0 & 1 & & & & \\
N A & 0 & N A & 0 & N A & 1 & & & \\
N A & 0 & N A & 0 & 0 & 0 & 1 & & \\
0 & 0 & N A & 0 & 0 & 0 & 0 & 1 & \\
N A & 0 & N A & N A & 0 & 0 & 0 & 0 & 1
\end{array}\right)
$$

The results of the model showed that on the whole sample, the exchange rate demonstrated a tendency to increase by $0,9 \%$, in every consequent period. At the same time, the signs at the regressors were standard following the monetary theory. However, the REER appreciation was supportive in reducing the real aggregate demand by $0.02 \%$, rising producer prices and core inflation by $1.4 \%$ and $3.4 \%$, respectively. Before the change in the foreign exchange rate regime, the exchange rate appreciation did not signal a rise in real aggregate demand. It only partially contributed to lower consumer price inflation, administratively regulated prices and core inflation. However, inflation expectations have improved slightly due to the strengthening of the exchange rate.

A negative sign of the regressor was observed at the indicator of trading conditions indicating a subsequent violation of the conventional interrelationships between the real exchange rate and the balance of foreign trade. After the introduction of the flexible exchange rate regime, in response, real GDP began to grow $(0.37 \%)$, and inflation decreased (except for prices for producers). Therefore, it can be stated that the change of the currency regime contributed to the convergence of the exchange rate and the foreign trade balance. In turn, it positively reflected the dynamics of inflation and improved the conductivity of the MTM pulse.

The correlation analysis of shocks showed that the results varied depending on the sample coverage period. Throughout the period from 2007 to July 2020, there was a negative correlation of all shocks except real GDP. Subsequently, during the so-called regime of fixed anchor, prices for consumer goods were positively correlated. However, it contradicts the classic notion that the real exchange rate appreciation contributes to their reduction. At the same time, aggregate consumption was correlated positively, which does not deny the hypothesis of rising consumption while strengthening the foreign exchange rate. During the same period, trade conditions were positively correlated, indicating the reduction of the trade deficit had an impact on the REER appreciation. Therefore, the result showed that market pricing of the exchange rate directly began to depend on the balance of foreign trade, as opposed to the period before 2014 . The analysis of shocks in each model demonstrated the idiosyncratic part of each variable's trend cause nonstandard reactions of the MTM variables in response to fluctuations in REER.

Furthermore, the duration of REER resistance in the context of different samples was different. The following dependence was found out: the longer the sample is, the longer the duration of half-life resistance is to the REER trend. Herewith, for the entire time period of 163 -time series, it was 41 months, or 3 years and 5 months. At the same time, in two smaller samples (87 and 76 rows), REER resistance persisted for only 6 and 14 months, respectively. This can be explained by the autoregression nature of REER, which grows with the growth of the sample size. 
A., Kuznyetsova, O., Klishchuk, A., Lisnyak, A., Kerimov, A., Babayev. Innovation Mechanism in Monetary Policy Forecasting: Unification of All Macroeconomic Puzzles in SVAR Model
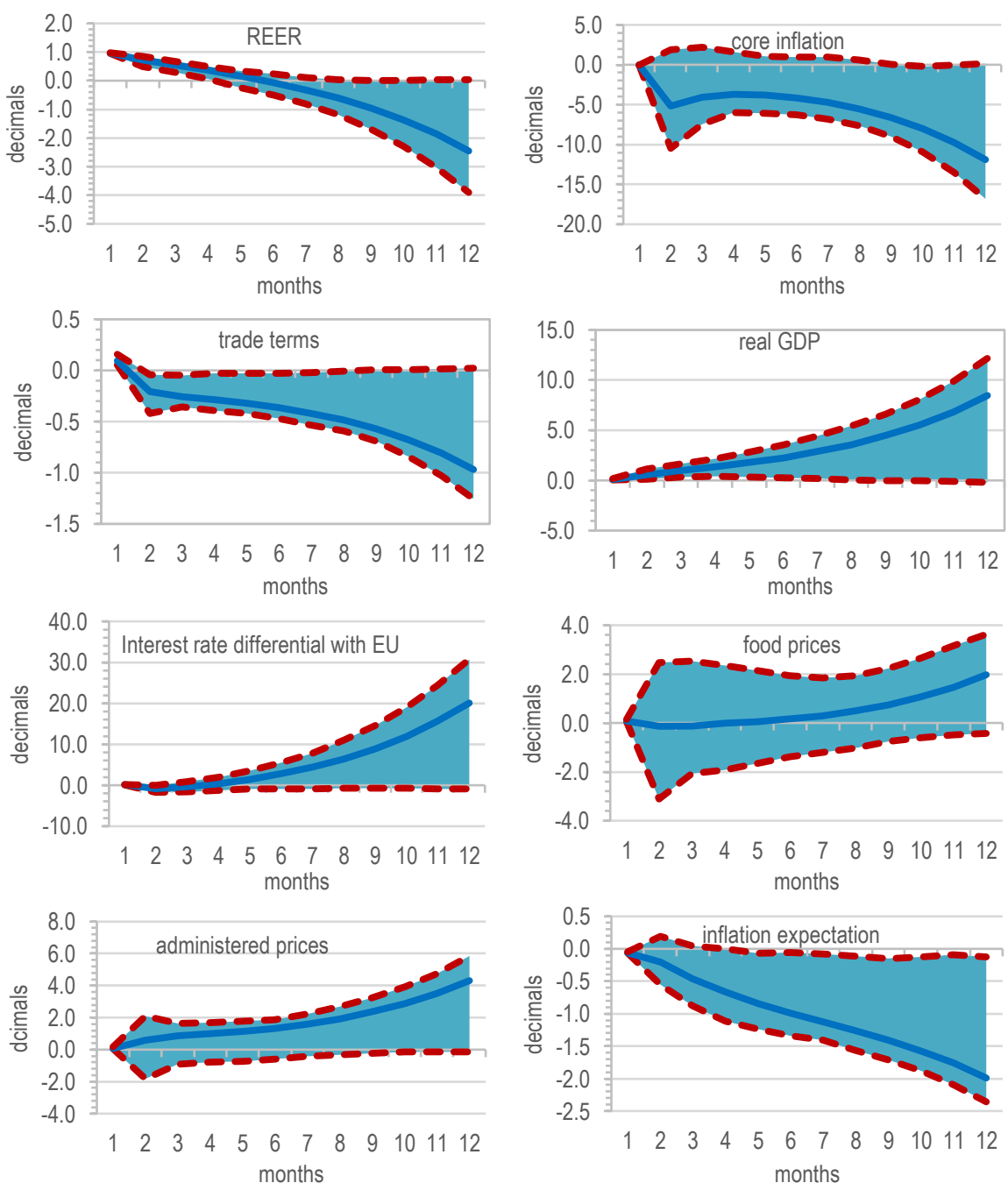

Figure 6. Impulse response functions to REER shock for the second sample (forecasts are presented in the differentiated form and at the $95 \%$ of confidence level)

Sources: developed by the authors. 


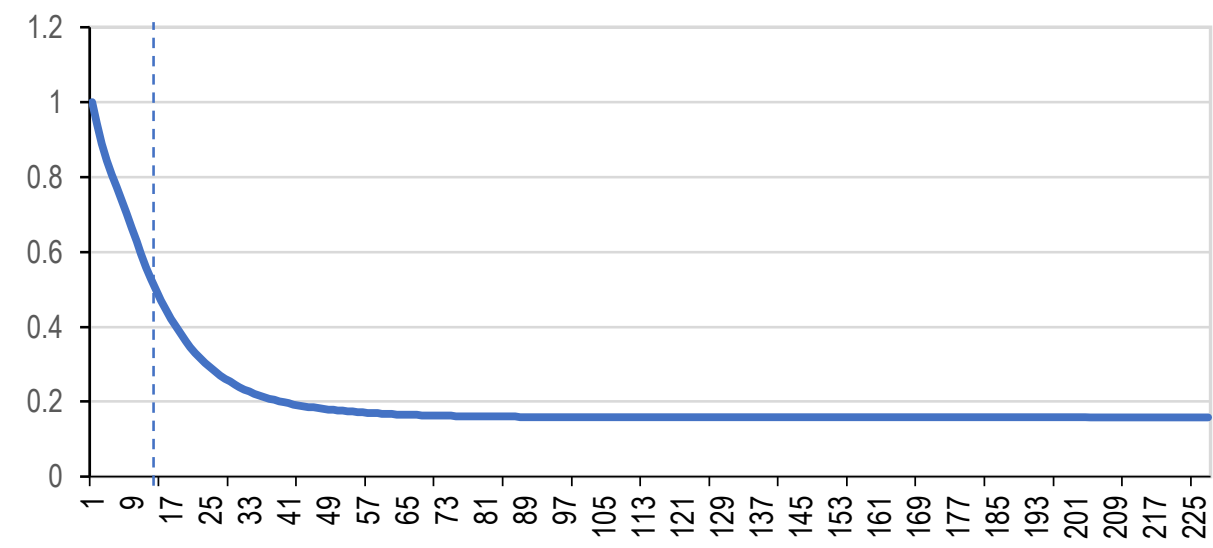

lag

Figure 7. Half-life duration of REER shock resistance

Sources: developed by the authors

Conclusions. The study findings confirmed the impact of the change in the currency regime on violations of traditional relations between the variables of the MTM foreign exchange channel. Thus, it shows that during the fixation of the exchange rate, absolutely all reactions were violated. Besides, the correlation coefficients of the REER and most variable MTM were correlated negatively. However, after the introduction of the flexible exchange rate of the hryvnia, the sign of the correlation between the REER and foreign trade terms has changed to a positive sign. Herewith, the strength of this connection has increased, which had a positive impact on the dynamics of real GDP and lower inflation.

Based on available literature and Ukraine example allowed confirming that the similar feature for all countries that the duration of resistance of the REER trend and found that this resistance over a 12-year sample was more than 3 years. That is, for changing the direction of the trend of the real exchange rate to change it is necessary 3 years and 5 months. This fact is connected with both the autocorrelative nature of the exchange rate, as well as the long period of fixing the exchange rate in Ukraine. At the same time, for two smaller samples divided before the event of switching to a flexible exchange rate regime, the halflife of the trend of the real exchange rate was much smaller.

Thus, it amounted to 6 months and more than 1 year respectively. The following dependence is fair for $\mathrm{X}$ : the longer the time series of macroeconomic variables are, the greater the duration of maintaining resistance to the trend change is. These conclusions could be used for improving the methodical approaches to establish structural restrictions on the response of macro variables to the shock of the exchange rate. Herewith, these variables take place in empirical data and could enhance the forecasting mechanism of exchange rate volatility and macroeconomic variables with using an offered algorithm for designing optimal monetary strategies.

Authors Contributions: conceptualization, A. K.; methodology, O. K. .; software, O. K.; validation, A. L.; formal analysis, A. K., O. K., At. K., A. B; investigation, A. K., O. K.; resources, A. L. At. K., A. B.; data curation, O. K.; writing - original draft preparation, A. K., O. K.; writing - review and editing, A. K., O. K., A. L., At. K., A. B.; supervision, A. K.

Funding: This research received no external funding. 


\section{References}

Atkeson, A., \& Burstein, A. (2008). Pricing-to-market, trade costs, and international relative prices. American Economic Review, 98(5), 1998-2031. [Google Scholar] [CrossRef]

Backus, D. K., \& Smith, G. W. (1993). Consumption and real exchange rates in dynamic economies with non-traded goods. Journal of International Economics, 35(3-4), 297-316. [Google Scholar] [CrossRef]

Baranovskyi, O. I. (2020). Regulation of functional and structural transformational processes in the financial sector. Financial and credit activity: problems of theory and practice, 1(32), 292-306. [Google Scholarl [CrossRef]

Baranovskyi, O. I. (2018). Quality of the transformational processes in the financial sector of the national economy: vectors of the measurement. Financial and credit activity: problems of theory and practice, 3(26), 350-367. [Google Scholar] [CrossRef

Benigno, G., \& Thoenissen, C. (2008). Consumption and real exchange rates with incomplete markets and non-traded goods. Journal of International Money and Finance, 27(6), 926-948. [Google Scholar] [CrossRef]

Boiarko, I. M. (2016). Praxeological and situational approaches in the formation of strategic accounting. Financial and credit activities: problems of theory and practice, 2(21), 80-90. [CrossRef]

Chari, V. V., Kehoe, P. J., \& McGrattan, E. R. (2002). Can sticky price models generate volatile and persistent real exchange rates?. The Review of Economic Studies, 69(3), 533-563. [Google Scholar] [CrossRef]

Engel, C. (2016). Exchange rates, interest rates, and the risk premium. American Economic Review, 106(2), 436-74. [Google Scholar] [CrossRef]

Hrytsenko, L. L., Roienko, V., \& Boiarko, I. M. (2018). Institutional background of the role of state in investment processes activation. Financial and credit activities: problems of theory and practice, 1(24), 338-344. [CrossRef]

Itskhoki, O., \& Mukhin, D. (2017). Exchange rate disconnect in general equilibrium (No. w23401). National Bureau of Economic Research. [Google Scholar] [CrossRef]

Kollmann, R. (1995). Consumption, real exchange rates and the structure of international asset markets. Journal of International money and finance, 14(2), 191-211. [Google Scholar] [CrossRef]

Kuznyetsova, A. Y., \& Klishchuk, O. V. (2017). Theoretical conception of price stability targeting arrangement: investigation of basic principles of implementation monetary regime. Financial and credit activity: problems of theory and practice, 2(23), 388-396. [Google Scholar] [CrossRef]

Meese, R. A., \& Rogoff, K. (1983). Empirical exchange rate models of the seventies: Do they fit out of sample?. Journal of international economics, 14(1-2), 3-24. [Google Scholar] [CrossRef]

Mussa, M. (1986). Nominal exchange rate regimes and the behavior of real exchange rates: Evidence and implications. In Carnegie-Rochester Conference series on public policy , 25, 117-214. North-Holland. [Google Scholar] [CrossRef]

National bank of Ukraine. (2020). External sector statistics of NBU. Retrieved from [Link]

National bank of Ukraine. (2020). Macroeconomic statistics of NBU. Retrieved from [Link]

National bank of Ukraine. (2020). Statistics of financial markets of NBU. Retrieved from [Link]

Petryk O. (2008). Way to price stability: international experience and perspectives for Ukraine: Kyiv, BU of NBU, 369-300.

Rekunenko, I. I., Hrytsenko, L. L., Boiarko, I. M., \& Kostyrko, R. A. (2019). Financial debt market in the system of indicators of development of the economy of the country. Financial and credit activities: problems of theory and practice, 2(29), 430-439.

Rogoff, K. (1996). The purchasing power parity puzzle. Journal of Economic literature, 34(2), 647-668. [Google Scholar]

State statistics service of Ukraine. (2020). System of national accounts. Retrieved from [Link]

Statistical Datawarehouse ECB. Retrieved from [Link]

Valchev, R. (2020). Bond convenience yields and exchange rate dynamics. American Economic Journal: Macroeconomics, 12(2), 124-66. [Google Scholar] [CrossRef]

Vovchak, O. D., Senyshch, P. M., \& Melnyk, T. V. (2019). «Purging» of the banking system: impacton the key performance indicators of banks. Financial and credit activity: problems of theory and practice, 1(28), 16-25. [Google Scholar] [CrossRef]

World Economic Outlook. (2020). Real GDP growth. Retrieved from [Link]

Анжела Кузнєцова, д.е.н., профессор, Університет банківської справи, Україна

Ольга Кліщук, Університет банківської справи, Україна

Андрій Лісняк, Університет банківської справи, Україна

Атік Керімов, Dr.Sc., профресор, Азербайджанський державний економічний університет, Азербайджан

Азер Бабаєв, Ph.D., доцент, Азербайджанський державний економічний університет, Азербайджан

Інноваційний механізм прогнозування монетарної політики: уніфікація макроекономічних проблем в SVAR моделі

Ця стаття присвячена розробці механізму прогнозування макроекономічних проблем, спричинених порушенням фундаментальних макроекономічних зв'язків між змінними монетарного трансмісійного механізму (МTM) в Україні. Автори наголосили, що порушення закону однієї ціни при формуванні валютного курсу, непокриті процентні ставки, ймовірність виникнення нових ускладнених фінансових інструментів та закономірності поширення ризику переміщення 
A., Kuznyetsova, O., Klishchuk, A., Lisnyak, A., Kerimov, A., Babayev. Innovation Mechanism in Monetary Policy Forecasting: Unification of all Macroeconomic Puzzles in SVAR Model

міжнародного фінансового капіталу є причинами порушення макроекономічної стабільності. У роботі проаналізовано кореляційні зв'язки між шоками та збуреннями в досліджуваних змінних за допомогою обчислення залишків векторної авторегресійної моделі МТМ. Отримані результати враховано при побудові матрииі обмежень структурної векторної авторегресійної моделі. У ході дослідження оиінено фуннкцію імпульсного відгуку з метою визначення тривалості шоку реального валютного курсу як однієї з основоположних причин порушення традиційних макроекономічних зв'язків. У результаті проведеного дослідження встановлено, що взаємозв'язки між макроекономічними змінними МТМ змінюються в залежності від встановленого валютного режиму. Зокрема, протягом 2007-2020 років було порушено взаємозв'язки між змінними МТМ, тоді як спад реального обмінного курсу був тривалішим. Автори відмітили, що в Україні до та після переходу на плаваючий валютний курс дані порушення стали менш вираженими, тоді як тривалість спаду шоку коротшою. За Результати дослідження засвідчили, що зміна режиму валютного курсу порушує традиційні взаємозв'язки між змінними валютного каналу МТМ, оскільки під час режиму фіксації валютного курсу абсолютно всі реакції були порушеними, а коефіицієнти кореляції РЕОК та низки змінних МТМ корелювались негативно. Однак, після впровадження плаваючогого валютного курсу, кореляція РЕОК та зовнішньоторгівельної діяльності стала позитивною. Таким чином, зростання щільності зв'язку позитивно вплинуло на динаміку реального ВВП та зниження інфрляції. Результати дослідження мають практичне значення і можуть бути прийняті до впровадження для вдосконалення методичних підходів до встановлення структурних обмежень у відповідь змінних на шок валютного курсу. При цьому алгоритм розробки оптимальних стратегій монетарної політики може бути застосованим при прогнозуванні волатильності валютного курсу.

Ключові слова: ПКС, НПП, МТМ, фінансові інновації, РEOK, SVAR.

Manuscript received: 13.02 .2020

(C) The author(s) 2020. This article is published with open access at Sumy State University 